BANK OF CANADA

1 BANQUE DU CANADA

Staff Working Paper/Document de travail du personnel - 2021-29

Last updated: June 21, 2021

\title{
A New Measure of Monetary Policy Shocks
}

by Xu Zhang

Financial Markets Department

Bank of Canada

Ottawa, Ontario, Canada K1A 0G9

XZhang@bank-banque-canada.ca

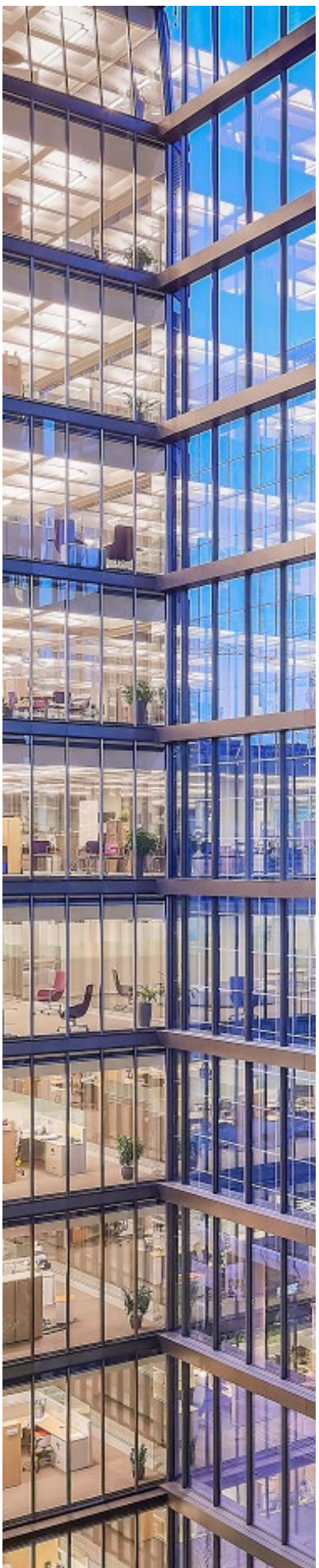

Bank of Canada staff working papers provide a forum for staff to publish work-in-progress research independently from the Bank's Governing Council. This research may support or challenge prevailing policy orthodoxy. Therefore, the views expressed in this paper are solely those of the authors and may differ from official Bank of Canada views. No responsibility for them should be attributed to the Bank. 


\section{Acknowledgements}

An earlier version of this paper was circulated under the title "Disentangling the Information Effects in the Federal Reserve's Monetary Policy Announcements." I thank James Hamilton, Johannes Wieland, Jason Allen, Rodrigo Sekkel, Jean-Sébastien Fontaine, Jonathan Witmer, Bruno Feunou and participants at various conferences for their helpful discussions. I thank the Federal Reserve Board for sharing the intraday futures movement data. I also thank Glenna M. Jenkins for her editorial assistance. 


\section{Abstract}

Combining the high-frequency multidimensional approach of Gürkaynak et al. (2005) with Greenbook measures of the Federal Reserve's information set as in Romer and Romer (2004), I propose a new method of constructing a monetary policy shock that occurs on Federal Reserve announcement days. I provide substantial evidence that the new monetary policy shock is consistent with the predictions of workhorse macroeconomic models for structural monetary policy shocks. The new shock has large and highly statistically significant instantaneous effects on the Treasury yield curve. Using the shock as an external instrument in a VAR analysis, I find that contractionary monetary policy has modest downward effects on both output and inflation over business-cycle frequencies.

Topics: Business fluctuations and cycles; Central bank research; Econometric and statistical methods; Interest rates; Monetary policy

JEL codes: E, E5, G, G0 


\section{Introduction}

Evaluating the causal effects of monetary policy is challenging. First, most movements in a policy action are the result of a systematic component of a policy rule. For example, the Federal Reserve (Fed) may lower the federal funds target when inflation is below target or when GDP growth is below potential. Second, the central bank may announce not only its current policy action but also release statements that could shape the market's expectation about the future interest rate path. The third challenge is that market participants might update their beliefs about the economic fundamentals or about the central bank's policy action rule after a policy announcement. For example, when the Fed announces that the economic conditions warrant an interest rate cut and this cut is more than market participants had anticipated, they may update their own beliefs that the economy is worse than they had originally thought. Thus, the overall reaction of the financial market to a Fed announcement could have two components: one caused by changes in the monetary policy stance, and one that is correlated with the economic conditions.

In this paper, I propose a new method of constructing a monetary policy shock. In response to the first challenge, I use the high-frequency identification approach pioneered by Cook and Hahn (1989) and Kuttner (2001) to exploit the fact that a disproportionate amount of monetary news is revealed around the window when Federal Open Market Committee (FOMC) announcements occur. To address the second challenge, where the Fed announcement reshapes the expectation for future monetary policy, I follow Gürkaynak et al. (2005) and use surprises for futures contracts settled in the current month and in subsequent months as instruments for innovations in the current rate and the expected future short rates. The third challenge is eliminated or at least heavily mitigated by regressing the various futures surprises mentioned above onto the Greenbook projections

for output growth and inflation to control for the confounding variables, in the spirit of Romer and Romer (2004), and then taking the principal components of the regression residuals.

I provide substantial evidence that a shock constructed in this way is a good instrument for a structural monetary policy shock. To study the immediate causal effect of monetary policy on 
financial markets, I regress the half-hour responses of various interest rates around the FOMC announcement onto the new monetary policy shock. I find that the shock has large and highly statistically significant effects on the entire yield curve. The peak effect is on the two-year Treasury yield. To evaluate the dynamic causal impact of monetary policy on the financial markets and the macro economy, I revisit the structural vector autoregression (SVAR) of Gertler and Karadi (2015), using the shock as an external instrument. I find that a contractionary monetary policy shock that, on impact, raises the one-year government bond yield by 25 basis points will lower industrial production by 0.15 percent and lower the CPI by 0.12 percentage points. The trough effect on industrial production is -0.25 percent after 18 months and then it gradually recovers.

There is an extensive literature on monetary policy shocks. Examples include Gertler and Karadi (2015), who use changes in three-months-ahead federal funds futures contracts, and MirandaAgrippino and Ricco (2018), who use components of the changes in the three-months-ahead fed funds futures contracts that could not be predicted using the Greenbook projections.

Recent studies challenge some of these monetary policy shocks. For example, Ramey (2016) states that it is "not a good feature" that the monthly shock series used in Gertler and Karadi (2015) has non-zero mean and is serially correlated.

I regroup the various tests performed in the literature and use six criteria to assess the quality of a given monetary policy shock as follows: 1) there should be no data gaps for the policy shock, especially for important subsample periods; e.g., the zero lower bond (ZLB) period; 2) the policy shock should have mean zero and be serially uncorrelated (Ramey, 2016); 3) it should not be predicted by an indicator of an NBER recession, economic news (Bauer and Swanson, 2020), or sentiment (Sastry, 2020); 4) it should be negatively correlated with private sector forecast revisions for inflation and positively for the unemployment rate (Campbell et al., 2012; Nakamura and Steinsson, 2018); 5) it should be negatively correlated with the stock market index (Jarociński and Karadi, 2019; Cieslak and Schrimpf, 2019); and 6) it should be consistent with the financial market commentary on important dates (Gürkaynak et al., 2005; Swanson, 2017; Gurkaynak et al., 
2020).

I show that none of the proposed measures in the literature satisfies all of the criteria. For example, private sector forecast revisions of the unemployment rate typically fall after a contractionary monetary policy shock, according to Kuttner (2001), Gertler and Karadi (2015) and Miranda-Agrippino and Ricco (2018), which is the opposite response from that predicted for a true contractionary monetary shock. If I apply other measures in the Gertler and Karadi (2015) SVAR, either a "price puzzle" or an "output puzzle" (responses to a monetary shock of the opposite sign predicted by workhorse macroeconomic models) appears.

In contrast, the new measure is actually positive on average (though far from statistically significant) during NBER recessions. This is the only measure for which revisions to private sector forecasts of both inflation and unemployment tend to change in the direction predicted for a monetary expansion or contraction. Furthermore, stock and bond prices move together in the way predicted by theory. Given the five-year delay in releasing Greenbook projections, the most recent value for the new measure is from December 2015, though this still extends the usable sample by at least six years beyond those available for the Kuttner (2001), Gertler and Karadi (2015), Romer and Romer (2004), or Miranda-Agrippino and Ricco (2018) measures.

This paper contributes to several important streams of literature. First, it adds to the monetary policy identification literature, especially papers identifying monetary policy surprises using high-frequency data on future interest rates observed in a narrow window around monetary policy announcements. Gürkaynak et al. (2005) construct a "current federal funds rate target" factor and a "future path of policy" factor using the first two principal components from various interest rate futures. Campbell et al. (2012) distinguish between Delphic and Odyssean monetary policy, where the Delphic type publicly states central banks' macroeconomic performance forecasts whereas the Odyssean type publicly commits the FOMC to a future policy action. To separate out the non-information movement, Nakamura and Steinsson (2018) model the Fed's information as beliefs about the path of the "natural rate of interest" and estimate a structural model using real 
rates. Jarociński and Karadi (2019), Cieslak and Schrimpf (2019), Andrade and Ferroni (2021), and Gürkaynak et al. (2021) separate out the information effects using the co-movement between interest rate futures and the stock price index, inflation swaps, and the exchange rate, respectively.

My paper also contributes to the literature that assesses the effects of unconventional monetary policies. Many of the world's largest economies have experienced zero or near-zero short-term nominal interest rates since late 2008. It is hard to find a measure for monetary policy surprises during this period. In addition, as Hamilton (2018) documents, similar to conventional monetary policy announcements, the Fed's unconventional monetary policy announcements also contain its assessments of economic fundamentals. Since I use longer-term eurodollar futures to construct the measure, it survives the zero lower bound period.

The remainder of this paper proceeds as follows. In Section 2, I formalize the six tests for a good monetary policy shock. In Section 3, I briefly review the literature on monetary policy identification. I describe the procedure used to construct the new monetary policy shock in Section 4. In Section 5, I compare the new measure with the existing measures, using the six tests presented in Section 2. In Section 6, I use the new measure to study the causal effects of monetary policy. Section 7 concludes. An online appendix provides further details of the data source and the robustness analyses.

\section{Features of a good monetary policy instrument}

What makes a monetary policy shock measure a good instrument? And how are these features tested in the literature? In this section, I review and group the various tests used in recent studies. First, in general, a shock series should have fewer data gaps and be updated as time goes by. If a shock cannot be updated, for example, due to a ZLB, then researchers and policy makers cannot rely on the shock series to directly study important subsample periods. Even when the monetary policy shock is used as an instrument in an SVAR that does not require the shock to have the same 
length as the other variables, ${ }^{1}$ the cost is that the short sample length usually makes the instrument less relevant. My test 1 for a good monetary policy shock is whether the shock series is continuous and available for the ZLB.

Second, a monetary policy shock is supposed to capture only unanticipated movements in the interest rate expectation (Ramey, 2016). The shock series, itself, should have zero mean and be serially uncorrelated. Thus, my second test is a white noise test.

Third, as in Bauer and Swanson (2020) and Sastry (2020), interest rate futures should incorporate all publicly available information up to the time the trades occur. Thus, the shock that is constructed using high-frequency futures data around the FOMC announcement should not be predictable from the publicly available information prior to the announcement. The third test is whether a shock can be predicted by, for example, NBER recessions, economic news and the prevailing sentiment regarding the announcement.

Furthermore, many macroeconomics textbooks - e.g., Romer (2002) and Galí (2015) and a broad range of papers; e.g., Smets and Wouters (2007)— have derived the effects of a structural monetary policy shock through the lens of micro-founded models. A contractionary monetary policy shock should increase the short-term interest rate, lower the output gap, lower inflation and increase the unemployment rate. As the fundamental value declines, the stock market valuation also falls.

The fourth test is whether a monetary policy tightening lowers private investors' expectations about inflation and increases their expectations about the unemployment rate, as in Campbell et al. (2012) and Nakamura and Steinsson (2018). The fifth test is whether the monetary policy shock co-moves negatively with the stock market index, as in Jarociński and Karadi (2019) and Cieslak and Schrimpf (2019).

Finally, the financial market commentary on Fed announcement dates typically directly attributes the move in the bond market to the specifics of the Fed announcement (Gürkaynak et al.,

\footnotetext{
${ }^{1} \mathrm{~A}$ common practice in keeping the exogeneity assumption valid is to use zeros to fill the values for the unavailable periods.
} 
2005; Swanson, 2017; Gürkaynak et al., 2021). A good monetary policy shock should be consistent with the market interpretation of whether the Fed's action is expansionary or contractionary. This is my sixth test.

\section{Existing approaches}

A number of studies propose alternative methods for measuring monetary policy shocks. In this section I will review the five existing approaches.

Surprise in the federal funds rate target (MP1). The high-frequency identification approach to measuring monetary policy shocks was pioneered by Kuttner (2001). Under the assumption that no other shocks affect the expectation for the federal funds rate around the 30-minute window of FOMC announcements, the surprise in the target rate is measured as the change in the spot-month federal funds future rate (FF1), scaled up to reflect the number of days affected by the change. This shock is called MP1 in the literature. As shown in Section 5, MP1 is serially correlated.

Change in three-months-ahead Federal funds futures ( $\triangle$ FF4). Gertler and Karadi (2015) use the three-months-ahead funds rate future surprise $(\triangle \mathrm{FF} 4)$ around the 30-minute window of the Fed's announcement to identify monetary policy shocks. As shown in Section $5, \triangle F F 4$ is also serially correlated.

Instrument set of futures (MP1, MP2, $\triangle$ ED2, $\triangle$ ED3, $\triangle$ ED4). Gürkaynak et al. (2005) find that FOMC statements affect the financial market through current policy action while also influencing market expectations of future policy actions. They suggest using mixed horizons of futures data to measure the market expectations response. I follow their method and use the following instrument set: MP1, the scaled surprises in the three-months-ahead monthly federal funds futures (known as MP2), and the surprises in the two-, three- and four-quarters-ahead futures on three-month eurodollar deposits (ED2, ED3, ED4) ${ }^{2}$ around the 30-minute window of the Fed's

\footnotetext{
${ }^{2}$ For EDn, the n-quarter(n)-ahead ED future is simply the nth contract with $\mathrm{n}=2,3,4$. The ED2 contract thus corresponds roughly to the 3-month forward rate that is two quarters out.
} 
announcement. $^{3}$

The shock that is constructed using the first principal component is labeled PC1. However, as will be shown, this shock can be predicted by using the economic news that is available before FOMC meetings.

The Romer and Romer (RR) shock. The seminal empirical paper on Fed information is Romer and Romer (2004). ${ }^{4}$ They construct their monetary policy shocks by combining the narrative approach with the Greenbook projections, which are economic projections produced by the Federal Reserve Board's staff and presented to the FOMC roughly one week prior to their policy meetings and are not available to the public until five years later. The intended federal funds rate changes during these FOMC meetings are derived using narrative methods. ${ }^{5}$ In order to separate the endogenous policy response to information about the economy from the exogenous policy deviation, the authors then regress the intended funds rate change on the Greenbook projections of output growth and inflation over the next two quarters. The specific equation they estimate in the second step is as follows: ${ }^{6}$

$$
\begin{aligned}
\triangle \mathrm{fft}_{m} & =\beta_{0} \mathrm{ff}_{\text {level }} m_{m^{-}}+\sum_{j=-1}^{2} \beta_{j}^{\triangle \mathrm{INFL}} \triangle \mathrm{INFL}_{m, q(m)+j}^{\mathrm{GB}}+\sum_{j=-1}^{2} \beta_{j}^{\triangle \mathrm{RealGDP}^{\prime}} \triangle \operatorname{RealGDP}_{m, q(m)+j}^{\mathrm{GB}} \\
& +\sum_{j=-1}^{2} \beta_{j}^{\mathrm{INFL}} \mathrm{INFL}_{m, q(m)+j}^{\mathrm{GB}}+\sum_{j=-1}^{2} \beta_{j}^{\mathrm{RealGDP}} \operatorname{RealGDP}_{m, q(m)+j}^{\mathrm{GB}}+\beta^{\mathrm{UNEMP}^{\mathrm{U}} \mathrm{UNEMP}_{m, q}^{\mathrm{GB}}(m)} \\
& + \text { constant }+\varepsilon_{m},
\end{aligned}
$$

where $\triangle \mathrm{fft}_{m}$ denotes the change in the federal funds target subsequent to the FOMC announce-

\footnotetext{
${ }^{3}$ Barakchian and Crowe (2013) use daily federal funds contracts for the current month and up to five months ahead due to data availability, while Gürkaynak et al. (2005) show evidence that intraday data isolates the response of asset prices to monetary policy announcements better than daily data do.

${ }^{4}$ Champagne and Sekkel (2018) and Cloyne and Hürtgen (2016) apply Romer and Romer's (2004) narrative approach to monetary policy shocks in Canada and the UK, respectively.

${ }^{5}$ Their meeting dates are very different from Gürkaynak et al. (2005), especially for the pre-1994 period. This difference is because the FOMC did not explicitly announce changes in its target for the federal funds rate, but such changes were implicitly communicated to financial markets through the size and type of the following open market operation. The day of the open market operation is used as the announcement date, as in Gürkaynak et al. (2005).

${ }^{6}$ This is equation 1 in Romer and Romer (2004).
} 
ment, $m$, and $\mathrm{ff}_{-}$level $m^{-}$is the level of the federal funds rate before any changes associated with the meeting. This is included to capture any tendency towards mean reversion in FOMC behavior. Let $q(m)$ be the quarter where the meeting, $m$, takes place. $\operatorname{INFL}_{m, q(m)+j}^{G B}$, $\operatorname{RealGDP}_{m, q(m)+j}^{G B}$ and $\mathrm{UNEMP}_{m, q(m)+j}^{G B}$ denote the Greenbook projections for inflation, real GDP and the unemployment rate for quarter $q+j$ made at meeting $m, \mathrm{j}=-1,0,1,2$, respectively. $\triangle \mathrm{INFL}_{m, q(m)+j}^{G B}$

and $\triangle \operatorname{RealGDP}_{m, q(m)+j}^{G B}$ are the revised forecasts for inflation and real GDP growth between two consecutive meetings, respectively.

The residual of this regression is labeled as a Romer-Romer shock. Due to the ZLB, this shock series could not be updated beyond 2007 and, thus, cannot be used to study the effects of unconventional monetary policy.

The Miranda-Agrippino and Ricco (MAR) shock. Miranda-Agrippino and Ricco (2018) regress the 30-minute window surprises in FF4 onto the Greenbook projections and use the residual to construct a monetary policy shock series. Next they sum the regression residuals within each month. Then they regress the non-zero monthly aggregation onto its 12 lags, and the residual is the MAR monetary policy shock. Since FF4 was near zero shortly after the Great Recession, their shock series could not be updated beyond 2009.

\section{Construction of the Path-Information-Robust (PIR) measure}

In this section, I lay out the procedure to construct a monetary policy shock that isolates the monetary stance from the confounding variables.

I assume that, within a half-hour narrow window around FOMC announcements, only two shocks systematically influence the financial market: a monetary policy stance shock and an "economic condition" shock. The monetary policy stance shock is the unexpected variation in the policy rate path. The economic condition shock is the fraction of the monetary policy surprise that is correlated with the economic condition. This correlation could either come from the private sec- 
tor inferring the economic condition from the Fed's action or from an alternative explanation put forward by Bauer and Swanson (2020), who note that the Fed overreacts to economic conditions.

To construct the new shock, I combine the high-frequency multidimensional approach of Gürkaynak et al. (2005) with the Greenbook measures of the Fed's information set, as in Romer and Romer (2004). The high-frequency instrument set gives me the advantage of capturing the movements in the financial markets that are caused by current and expected future policy actions, and the Greenbook projections give us a nice proxy for what the Fed believed about the economic conditions before the FOMC meeting. In particular, I proceed in the following five steps.

Step 1. Following Kuttner (2001) and Gürkaynak et al. (2005), I build the unanticipated change, over the 30-minute windows, in the following five interest rates: the scaled current month's federal funds target rate (MP1), the three-months-ahead federal funds futures (FF4), and the two-, three- and four-quarters-ahead futures on three-month eurodollar deposits (ED2, ED3, ED4). ${ }^{7}$ It is very unlikely that other economic news that may have influenced asset prices would have been released within such a brief interval of time, and the FOMC's decision is not made in response to asset price movements or macroeconomic news. ${ }^{8}$

I restrict the samples for MP1 and FF4 to end in December 2008 and December 2009, respectively, since their rates show little variation and their trading volumes are low after those dates. The sample period for ED2, ED3 and ED4 is from January 1988 to December 2015. ${ }^{\text {The scheduled }}$ and unscheduled FOMC announcements are both included in each sample period.

Step 2. I regress these surprises, $M P 1, \triangle F F 4, \triangle E D 2, \triangle E D 3, \triangle E D 4$, onto (i) the level of the futures interest rate one day before the FOMC meeting to capture the mean reversion in the FOMC

\footnotetext{
${ }^{7}$ The results in Sections 5 and 6 are robust if we add ED5 and ED6 to construct the new measure.

${ }^{8}$ Following the literature, here; e.g., Gürkaynak et al. (2005), Campbell et al. (2012), Swanson (2017), and Nakamura and Steinsson (2018), I exclude the FOMC announcement of September 17, 2001, which took place before the markets opened but after the financial markets had been closed for a few days following the $9 / 11$ terrorist attacks (Swanson, 2017).

${ }^{9}$ On August 9, 2011, the FOMC announced that the current level of the federal funds rate would be appropriate "at least through mid-2013." However, the trade volume, an indicator of market activity and liquidity, is still quite high afterwards. The results in Sections 5 and 6 still hold if the sample for the period between September 2011 and November 2013 is excluded for ED2 and ED3.
} 
behavior; and (ii) the Greenbook projections and their revisions for real output growth, inflation and the unemployment rate, as in Romer and Romer (2004), to control for the central bank's private information. The specific equation I estimate is

$$
\begin{aligned}
& \mathrm{MPS}_{d}=\beta_{0} \mathrm{MPS} \_ \text {level }_{d^{-}}+\sum_{j=-1}^{s} \beta_{j}^{\triangle \mathrm{INFL}} \triangle \mathrm{INFL}_{d, q(d)+j}^{\mathrm{GB}}+\sum_{j=-1}^{s} \beta_{j}^{\triangle \mathrm{RealGDP}} \triangle \mathrm{RealGDP}_{d, q(d)+j}^{\mathrm{GB}} \\
& +\sum_{j=-1}^{s} \beta_{j}^{\mathrm{INFL}} \mathrm{INFL}_{d, q(d)+j}^{\mathrm{GB}}+\sum_{j=-1}^{s} \beta_{j}^{\mathrm{RealGDP}} \operatorname{RealGDP}_{d, q(d)+j}^{\mathrm{GB}}+\sum_{l=0}^{m} \beta_{j}^{\mathrm{UNEMP}} \mathrm{UNEMP}_{d, q(d)+j}^{\mathrm{GB}} \\
& + \text { constant }+\varepsilon_{d},
\end{aligned}
$$

where $\mathrm{MPS}_{d}$ denotes the market-based monetary policy surprise on the Fed's announcement day $d$, MPS $\_$level $d^{-}$is the futures daily interest rate on the trading day prior to the meeting, and all of the other variables are defined in the same way as in equation 1.

The forecast horizons $s$ and $m$ vary among the five regressions. In particular, I use forecasts up to two quarters ahead; i.e., $s=2$ for MP1 and $\triangle \mathrm{FF} 4$, and I use $s=3$ for $\triangle \mathrm{ED} 2, \triangle \mathrm{ED} 3$ and $\triangle$ ED4. Following Romer and Romer (2004), I only include the contemporaneous unemployment rate forecast for MP1 and $\triangle \mathrm{FF} 4$; i.e., $\mathrm{m}=0$, and the unemployment rate forecast up to one quarter ahead for $\triangle \mathrm{ED} 2, \triangle \mathrm{ED} 3$ and $\triangle \mathrm{ED} 4$; i.e., $\mathrm{m}=1$.

The results of estimating equation 2 are reported in the online appendix. The R-squared statistics of the five regressions are $0.16,0.15,0.18,0.19$ and 0.17 for MP1, $\triangle \mathrm{FF} 4, \triangle \mathrm{ED} 2, \triangle \mathrm{ED} 3$ and $\triangle \mathrm{ED} 4$, respectively. This suggests that the sizable fraction of the interest rate expectation that changes around the FOMC announcement is due to the Fed's projections of past, current and future growth and inflation. ${ }^{10}$

Step 3. I normalize the residuals of each regression to have zero mean and unit variance, similar to the procedure in Gürkaynak et al. (2005).

The different sample periods for the interest rate futures lead to different sample periods for

\footnotetext{
${ }^{10}$ By comparison, the R-squared statistic is 0.28 in Romer and Romer (2004), who use the FOMC meetings that took place from March 1969 to December 1996.
} 
the residuals. I therefore use the expectation maximization (EM) algorithm developed in Stock and Watson (2002) to calculate the principal components of the unbalanced panel of the residuals. ${ }^{11}$

Step 4. Following Barakchian and Crowe (2013) and Nakamura and Steinsson (2018), I only look at the first principal component, ${ }^{12}$ which explains 81 percent of the variation. I rescale the first principal component such that the effect on the daily two-year nominal Treasury yield ${ }^{13}$ is equal to 100 basis points. This is the monetary policy shock series at the announcement frequency. It has 264 observations.

The correlations of this new measure with MP1, FF4, PC1 and the MAR are 0.74, 0.82, 0.90 and 0.85 , respectively, if we are using the full sample of each series, and 0.75, 0.81, 0.93 and 0.85, respectively, if we are using the sample period between January 1990 and December 2007. However, if we only look at the announcements released during the NBER recession periods, the correlations become $0.01,0.09,0.1$, and 0.08 , respectively. This also indicates that the information effects are asymmetric and more prevailing during a recession.

Step 5. To obtain monthly frequencies, I assign each shock to the month in which the corresponding Fed announcement occurs. If there are two announcement days in a month, then I sum the shocks. If there are no meetings in a month, then I record the shock as zero for that month.

I refer to this monetary policy measure as a "path-information-robust" (PIR) measure, which is a combination of the "path factor" in Gürkaynak et al. (2005) and the "information-robust" factor in Miranda-Agrippino and Ricco (2018). The use of longer horizon eurodollar futures allows the new measure to span from January 1988 to December 2015 and to be updated in the future as the Fed releases more Greenbook projections.

\footnotetext{
${ }^{11}$ Specifically, I first normalize each series to have zero mean and unit variance. I then recover the first factor using a balanced panel. Then this factor is used to impute the values of the missing observations and then to do the factor analysis again, iterating on this procedure until it converges.

${ }^{12}$ Nakamura and Steinsson (2018) use the same interest rate futures as in Gürkaynak et al. (2005) and find that the first principal component is closely related to Gürkaynak et al.'s (2005) "path factor."

${ }^{13}$ The daily zero-coupon nominal Treasury yields are obtained from Gürkaynak et al. (2007).
} 


\section{Comparing Various Monetary Policy Surprises}

In this section, I evaluate the performance of various monetary policy surprise measures, using the six tests described in Section 2.

For the different measures of the monetary policy shocks to be comparable, I rescale all of these measures (except the RR since the date is different from the others) such that their effects on the daily two-year nominal Treasury yield are each equal to 100 basis points. ${ }^{14}$ To convert the shock series to monthly frequencies (except the MAR, since the authors have constructed a monthly shock), I assign each shock to the month in which the corresponding FOMC announcements are made. If there are two meetings in a month, I sum the shocks. If there are no meetings in a month, I record the shock as zero for that month.

\section{Test 1: Data continuity and availability for the zero lower bound period}

In Figure 1, I plot the cumulative monetary policy surprises over a 12-month rolling window. MP1 and $\triangle F F 4$ are almost zero during the period between 2009 and 2015. The Romer-Romer shock starts from March 1969 and ends in December 2007. ${ }^{15}$ The monthly MAR series begins in January 1991 and ends in December 2009.

Figure 2 presents graphs of the intraday movements of the trading volume of FF4 for each of the announcement dates between January 2011 and December 2013. This is based on the Time and Sales data from the CME Group (Chicago Mercantile Exchange, Chicago Board of Trade, New York Mercantile Exchange, The Commodity Exchange), and each dot represents each entry in the CME's official records of electronic trade times and volumes. The solid vertical lines indicate the announcement times. The dashed vertical lines represent the time ten minutes before and twenty minutes after each announcement. These graphs show that there are very low trading volumes for

\footnotetext{
${ }^{14}$ Swanson and Williams (2014) provide evidence that the zero lower bound is not a constraint on the Federal Reserve's ability to manipulate the two-year Treasury yield.

${ }^{15}$ Wieland and Yang (2020) extend the original Romer-Romer shock series to the end of 2007.
} 
FF4 between 2011 and 2013. The possible reason is that the use of forward guidance policy anchors the market's expectation for the next three months' interest rate path, as discussed in (Swanson and Williams, 2014).

The data discontinuity makes it impossible to apply MP1, $\triangle \mathrm{FF} 4$, the RR and the MAR to coherently study the monetary policy effects on recent recessions and to update the data for future recessions as long as the ZLB appears.

On the other hand, as shown in Figure 3, the trading volumes of ED4 are still high during these periods. This is also the case for ED5 to ED8. The use of these eurodollar futures allows PC1 and the PIR to survive the ZLB.

\section{Test 2: White noise}

The first row of Table 1 shows the sample average of each shock. I then perform a Ljung-Box Q-test under the null hypothesis that a series of residuals exhibits no autocorrelation for a fixed number of lags against the alternative that some autocorrelation coefficient is nonzero.

As shown in the table, the means of the MP1 and $\triangle F F 4$ series are non-zero and all measures except the MAR and the PIR are serially correlated.

\section{Test 3: Predictability using NBER recessions, economic news and sentiment}

The shaded areas in Figure 1 represent NBER-defined recession months for the U.S. economy. From the figure, we can see that MP1 is more likely to be negative during NBER recession months. The Fed surprises the market with lower interest rates during these recessions and it does this because it sees the economy as being weaker than many private analysts recognize at the time.

To quantify this observation, I regress the monthly monetary policy surprises on an NBER recession indicator that equals 1 if the month is an NBER recession month and 0 otherwise. If we use MP1, then the estimated coefficient is -0.03 and is statistically significant at the 1 percent level. If we were to use MP1 to study the correlation between a monetary shock and the economic 
variables of interest, then this would, in part, reflect the effect of the recession and not the effect of Fed actions.

For the performance of $\triangle \mathrm{FF} 4$ and $\mathrm{PC} 1$, again, the coefficients obtained from regressing monthly monetary policy surprises on the NBER recession indicators are -0.03 and -0.03 , respectively; both are statistically significant at the 1 percent level. The coefficients for the RR and the MAR are -0.09 and -0.01 , though insignificant. The NBER recession coefficient for the PIR is 0.00 and insignificant.

Bauer and Swanson (2020) and Sastry (2020) find that economic news and public sentiment can predict Nakamura and Steinsson's (2018) monetary policy surprises. I reproduce their analysis by regressing various measures of monetary surprises on the economic news and sentiments that are available before the meetings. The economic news used includes nonfarm payroll, the Chicago Fed's "big data" business cycle indicator, according to Brave et al. (2019), and the percent change in the daily SP 500 index from thirteen weeks prior to an FOMC announcement, to the day before a subsequent FOMC announcement. The bullish and bearish sentiments are from the weekly American Association of Individual Investors sentiment survey, which measures the percentage of individual investors who are bullish, bearish, and neutral on the stock market in the short term. Table 2 presents the results. Each coefficient is from one OLS regression at the meeting frequency. Only the PIR measure, shown in the last column, cannot be predicted by the news or the market sentiment.

One possible explanation is that the Greenbook projections are made roughly one week ahead of each FOMC meeting and contain their backcasts, nowcasts, forecasts and revisions of real GDP growth, inflation and the unemployment rate. These projections are highly correlated with the economic news and sentiment prevailing at these meetings. Indeed, if we regress the five different economic news and sentiment measures on the Greenbook projections, then the R-squared statistics from the five regressions are quite high: $0.69,0.77,0.61,0.31$ and 0.33 , respectively. 


\section{Test 4: Effects on private sector forecast revisions}

Next I follow Campbell et al. (2012) and estimate the revisions to inflation and unemployment rate forecasts in response to the proposed monetary policy measure. The regression equation is

$$
\triangle \mathbf{B C}_{t+1}^{h}=\beta^{h} \mathrm{MPS}_{t}+\text { constant }+\varepsilon_{t+1},
$$

where $\triangle \mathrm{BC}_{t+1}^{h}$ is the revision of the h-quarters-ahead Blue Chip consensus forecasts of inflation and the unemployment rate at the beginning of month $t+1 ; h=0,1,2,3,4$; and MPS is $_{t}$ the monetary policy surprise in month $t$.

In workhorse macroeconomic models, a true contractionary monetary policy shock should increase the unemployment rate expectation and decrease the inflation expectation.

Table 3 presents the regression results. ${ }^{16}$ Each coefficient is from one OLS regression. In sharp contrast to the conventional theory of monetary shocks, most coefficients in column 1 show the opposite direction. The interpretation is that part of what happens is the Fed raises the interest rate because it sees the fundamentals as being stronger and private forecasts respond to this signal by being more optimistic about the fundamentals. All of the responses to the unemployment rate forecasts in column 2 are negative. The coefficients in column 3 are usually the opposite of what we would expect from workhorse macroeconomic models. Contractionary monetary policy Romer-Romer shocks seem to increase the inflation expectation, which is not true according to theory. For the MAR monetary policy shock, ${ }^{17}$ almost all of the coefficients are insignificant from zero and all of the unemployment rate revision responses go in the opposite direction, as workhorse macroeconomic models would predict. Columns 6 and 7 show the estimated private forecast responses to the new PIR measure. Following a contractionary monetary policy news shock, current

\footnotetext{
${ }^{16}$ The Blue Chip Economic Indicators survey is conducted between the 2nd and 7th day of each month. The monetary surprise data I use for this regression is restricted to include only the announcements made after the first week of the calendar month. As shown in the online appendix, the result is robust if I use the observations where the entire month's announcements are made after the first week of that calendar month.

${ }^{17}$ The meeting frequency measure is used.
} 
and expected unemployment rates tend to increase and current and expected inflation rates tend to fall. Thus, the contractionary monetary policy shock behaves as predicted by theory.

\section{Test 5: Co-movement with the stock market index}

Cieslak and Schrimpf (2019) and Jarociński and Karadi (2019) look at the information effects from the perspective of the co-movement of the S\&P 500 with bond yields. Again, a true contrac-

tionary monetary policy shock should raise interest rates and depress output, both of which should lower stock prices and the price of the stock index's futures.

To quantify the relationship between the 30-minute changes in stock prices and the monetary policy surprises, I construct two correlations: a linear Pearson correlation coefficient (Table 4, panel A), which captures the statistical dependence between the levels of the two variables, and a Spearman index of rank correlation (Table 4, panel B), which is a non-parametric measure and captures the degree to which a relationship is monotonic. Spearman's correlation (unlike Pearson's correlation) is successful in small samples and is robust to outliers (Gnocchi et al., 2015).

Table 4, column 1, shows that the linear correlation between MP1 and the changes in the S\&P 500 is -0.58 , but the rank correlation is only -0.38 . PC1 and the PIR are the two measures whose correlations with the stock index are quite negative compared to all of the other measures. Surprisingly, if we use the Romer-Romer shock, the correlation is positive.

\section{Test 6: Consistency with financial market commentary on important dates}

Another way to validate the direction of monetary policy surprises is to check whether the monetary policy is consistent with the financial market commentary found in the Wall Street Journal, an approach used in Gürkaynak et al. (2005), Swanson (2017) and Gurkaynak et al. (2020).

In Table 5, I report the details on ten important event days that occurred between 1990 and 2004. These dates and the corresponding financial market commentary are from the original Table 4 of Gürkaynak et al. (2005). In Table 6, I report another six important event days that occurred between 
2004 and 2015. Those days are selected such that they include the largest three PIR observations when all of the measures move in the same direction and the largest three PIR observations when at least one measure disagrees with the rest.

February 4, 1994, marks the Fed's first tightening action in about five years to "sustain and enhance the economic expansion." Due to the "small increase," investors expect this would bring little change to the economy and that there would be an increase in the federal funds rate over the next year (The Wall Street Journal, 1994). Thus, the announcement is more likely to be a tightening surprise. MP1, PC1, the RR and the PIR all interpret it in this way. But no changes occur in FF4 and the MAR assigns this as an expansionary surprise.

The Fed's decision on January 28, 2004, to leave the current federal funds rate unchanged is completely anticipated by the market, but replacing the phrase "policy accommodation can be maintained for a considerable period" with "the Committee believes it can be patient in removing its policy accommodation" is read by financial markets as a signal that policy would tighten sooner than previously expected (Gürkaynak et al., 2005). Thus the announcement is more likely to be one of a tightening policy. MP1 and $\triangle \mathrm{FF} 4$ are positive but quite small, and the large and positive changes in eurodollar futures are the major contributors to PC1 and the PIR. However, the RR and the MAR go in the opposite direction.

Two Fed announcements are made on November 25, 2008. One is the initial announcement that the Fed would purchase up to $\$ 100$ billion of agency debt and up to $\$ 500$ billion of agency mortgage-backed securities (MBS). Another is the creation of the Term Asset-Backed Securities Loan Facility (TALF), which would offer one-year financing. The financial markets are optimistic that these lending facilities could prevent deflation (The Wall Street Journal, 2008a) and bring back mortgage-debt buyers (The Wall Street Journal, 2008b). MP1 and $\triangle F F 4$ are negative though negligible, while the changes in the eurodollar futures are large and negative. The RR shock is unavailable. MP1 and $\triangle \mathrm{FF} 4, \mathrm{PC} 1$ and the PIR assign this announcement as an expansionary monetary policy surprise while the MAR assigns it as being contractionary. 
On March 18, 2009, the Fed's statement began with "information received since the Federal Open Market Committee met in January indicates the economy continues to contract," which is consistent with revisions to the Greenbook projections, which at the meeting are the second-, third-, and largest downward revisions in history, between 1988 and 2015, for the backcast, and the 2-quarters-ahead and 3-quarters-ahead forecasts of real output growth. The inflation revisions are similar. The FOMC then announced it would keep a near-zero target rate "for an extended period" and would purchase more than $\$ 1$ trillion in Treasury and mortgage-backed securities. The statement also dropped any reference to the economy recovering "later this year," hinting at the reasons for its drastic move in bond purchases (The Wall Street Journal, 2009). MP1 and the change in FF4 are very negligible, and the change in eurodollar futures are negative and medium. ${ }^{18}$ PC1 indicates that this day is a medium-size expansionary surprise, but the MAR and the PIR, considering the large downward forecast revisions, assign it as a tightening monetary policy shock.

Table 7 summarizes whether a shock has passed the test or not. All of the above-mentioned monetary policy shocks still seem to have an important signaling component. They tend on average to be pro-cyclical, as if the Fed were lowering rates during recessions for some reason other than a response to the perceived economic conditions. The PIR uses interest rate futures contracts to pin down the expected path of the federal funds rate and isolates the pure monetary policy shock from the signaling component. The new shock series is consistent with the financial market perceptions on the event days.

\section{Causal Effects of Monetary Policy}

I have demonstrated how the new measure is constructed to overcome the three challenges mentioned at the beginning of this paper. We are equipped with a tool that sheds light on the core empirical issue in monetary economics: how large the short- and long-run causal effects of

\footnotetext{
${ }^{18}$ For ED2, ED3 and ED4, trading volumes are large around the statement release.
} 
monetary policy are on the financial and macro variables.

To address this issue, I conduct two analyses: 1) an event study that evaluates the instantaneous causal effects of monetary policy on financial variables, and 2) the use of a proxy structural vector autoregression model to evaluate the short- and long-run causal effects of monetary policy on the macroeconomic and financial variables.

\subsection{Event study regressions}

In Table 8, I report the responses of various market interest rate changes (nominal Treasury yields and inflation-indexed Treasury (TIPS) yields ), in a half-hour window around the FOMC announcement, to different monetary policy shocks. Each coefficient in the table is obtained from an OLS regression. Nominal yields respond significantly to all of the monetary policy shocks except the RR.

The last column indicates that a PIR shock that increases the two-year nominal Treasury yield by 100 basis points will increase the 3- and 6-month and five-, 10- and 30-year Treasury yields by $75,90,80,46$ and 18 basis points, respectively. The peak effects appear at the two-year rates because this measure incorporates the expectation of a future policy rate path. This also indicates that it could capture the effects of forward guidance, a type of unconventional monetary policy tool that is used to gauge the market's expectation.

For the TIPS, all of the shocks except the RR have significant effects on all of the maturities. A PIR shock that increases the two-year nominal Treasury rate by about 100 basis points will increase the two-year TIPS rate by about 83 basis points.

\subsection{Proxy structural vector autoregression}

I assess the dynamic impact of monetary policy by using the proxy structural VAR specification as in Gertler and Karadi (2015). This is a 12-lag monthly VAR that uses monetary policy surprises as an external instrument. Miranda-Agrippino and Ricco (2018) follow Coibion (2012) and extend 
the framework to six variables: the log of industrial production, the unemployment rate, the $\log$ of the CPI, the log of a commodity price index, the excess bond premium (Gilchrist and Zakrajšek, 2012) and the one-year Treasury yield. ${ }^{19}$

Following Ramey (2016), I look at the subsample period from January 1983 to December 2007, which excludes the period of non-borrowed reserve targeting under Paul Volcker and that of the Great Recession.

Before conducting the estimation, I use the F-statistic provided by Montiel Olea et al. (2020) to test the relevance condition required for the identification. The F-statistic provides an indication of possible weak-instrument concerns for the inference with a 5 percent critical value of 3.84 . The F-statistics are 5.47, 12.04, 8.40, 12.25, 6.10 and 8.49 when we instrument the monetary policy shock using MP1, $\triangle \mathrm{FF} 4, \mathrm{PC} 1$, the Romer-Romer, the MAR and the PIR, respectively. Thus, we conclude that all of the measures are relevant, though not strong, instruments.

Figure 4 plots the impulse responses that follow a monetary policy shock that, on impact, raises the one-year government bond yield by 25 basis points, using the new measure, PC1 and the MAR shock, respectively. The 68 percent confidence interval is constructed using the inference approach of Montiel Olea et al. (2020) for a weak instrument. ${ }^{20}$

Ramey (2016) summarizes the leading specifications that study the effects of monetary policy shocks on output and prices. Her findings suggest that contractionary monetary policy shocks appear to be expansionary (the so called "price puzzle" and "output puzzle") and that the problem becomes worse when using recent sample periods.

However, using the PIR measure, the estimates imply that a shock that raises the bond yield is still contractionary: in response to a contractionary monetary policy shock that on impact raises the one-year government bond yield by 25 basis points, industrial production immediately drops by 0.15 percent and the CPI drops by 0.12 percentage points. The trough effect on industrial

\footnotetext{
${ }^{19}$ I use the monthly average.

${ }^{20}$ Mertens and Ravn (2019) provide a brief overview of the existing methods for inference in proxy SVARs. I follow their method, which assigns zeros to the external instrument variable if its sample period is shorter than the sample period of the VAR variables.
} 
production is -0.25 percent after 18 months and it then gradually recovers.

What is striking here is that if we use PC1 or the MAR, the initial responses of industrial production and the unemployment rate go in the wrong direction and are sometimes significant (industrial production for the MAR and the unemployment rate for PC1). In Figure 5, I show that a contractionary RR shock that increases the one-year Treasury yield on impact will also increase the price level, and both the contractionary MP1 and $\triangle \mathrm{FF} 4$ will lower the unemployment rate. If a policy maker wants to make a decision in response to a recession, based on Figures 4 and 5, the PIR shock will suggest a lower interest rate while all of the other measures will suggest an increase in the rate.

If we use data up to December 2015 (after which the PIR becomes unavailable), or December 2018, then the PIR measure still produces impulse responses that are consistent with the conventional wisdom. The estimation details are provided in the online appendix.

\section{Conclusion}

Evaluating the effects of monetary policy is important for both policy makers and researchers. However, it is very challenging to identify the non-systematic movements in monetary policy instruments. In this paper, I provide a new method of constructing monetary policy shocks that can be used to study the causal effects of monetary policy on financial and macroeconomic variables, and I compare this method with existing approaches.

The new measure, which I label as "path information robust," combines innovations to the rates in the current month with those anticipated in the future. It successfully isolates the exogenous noninformation movement of the Federal Reserve's announcement, whereas the previous methods are incapable of achieving this. This is consistent with the standard theory's predictions: that a monetary policy shock is independent of a recession period; a pure monetary policy tightening lowers private investors' expectations about inflation and output growth; and the majority of the 
co-movements between the S\&P 500 and the monetary policy shocks are negative. Furthermore, the new measure can be used as a relevant instrument for a proxy-SVAR analysis. The "price puzzle" and "output puzzle" disappear in the analysis.

The methodology used for constructing monetary policy shocks can also be applied when analyzing monetary policy in other advanced economies, such as Canada and the UK. 


\section{References}

Andrade, P. and F. Ferroni (2021). Delphic and odyssean monetary policy shocks: Evidence from the euro area. Journal of Monetary Economics 117, 816-832.

Barakchian, S. M. and C. Crowe (2013). Monetary policy matters: Evidence from new shocks data. Journal of Monetary Economics 60(8), 950-966.

Bauer, M. and E. Swanson (2020). The fed's response to economic news explains the "fed information effect". NBER Working Paper.

Brave, S., A. Butters, and D. Kelley (2019). A new "big data" index of U.S. economic activity. Federal Reserve of Chicago Working Paper.

Campbell, J. R., C. L. Evans, J. D. Fisher, and A. Justiniano (2012). Macroeconomic effects of federal reserve forward guidance. Brookings Papers on Economic Activity 2012(1), 1-80.

Champagne, J. and R. Sekkel (2018). Changes in monetary regimes and the identification of monetary policy shocks: Narrative evidence from Canada. Journal of Monetary Economics 99, $72-87$.

Cieslak, A. and A. Schrimpf (2019). Non-monetary news in central bank communication. Journal of International Economics 118, 293-315.

Cloyne, J. and P. Hürtgen (2016). The macroeconomic effects of monetary policy: A new measure for the United Kingdom. American Economic Journal: Macroeconomics 8(4), 75-102.

Coibion, O. (2012). Are the effects of monetary policy shocks big or small? American Economic Journal: Macroeconomics 4(2), 1-32.

Cook, T. and T. Hahn (1989). The effect of changes in the federal funds rate target on market interest rates in the 1970s. Journal of Monetary Economics 24(3), 331-351. 
Galí, J. (2015). Monetary policy, inflation, and the business cycle: An introduction to the new Keynesian framework and its applications. Princeton University Press.

Gertler, M. and P. Karadi (2015). Monetary policy surprises, credit costs, and economic activity. American Economic Journal: Macroeconomics 7(1), 44-76.

Gilchrist, S. and E. Zakrajšek (2012). Credit spreads and business cycle fluctuations. American Economic Review 102(4), 1692-1720.

Gnocchi, S., A. Lagerborg, and E. Pappa (2015). Do labor market institutions matter for business cycles? Journal of Economic Dynamics and Control 51, 299-317.

Gürkaynak, R. S., A. H. Kara, B. Kısacıkoğlu, and S. S. Lee (2021). Monetary policy surprises and exchange rate behavior. Journal of International Economics 130, 103-443.

Gurkaynak, R. S., B. Kisacikoğlu, and J. H. Wright (2020). Missing events in event studies: Identifying the effects of partially measured news surprises. American Economic Review 110(12), $3871-3912$.

Gürkaynak, R. S., B. Sack, and E. Swanson (2005). Do actions speak louder than words? The response of asset prices to monetary policy actions and statements. International Journal of Central Banking 1(1), 55-93.

Gürkaynak, R. S., B. Sack, and J. H. Wright (2007). The US Treasury yield curve: 1961 to the present. Journal of Monetary Economics 54(8), 2291-2304.

Hamilton, J. D. (2018). The efficacy of large-scale asset purchases when the short-term interest rate is at its effective lower bound. Brookings Papers on Economic Activity 2018(2), 543-554.

Jarociński, M. and P. Karadi (2019). Deconstructing monetary policy surprises: The role of information shocks. American Economic Journal: Macroeconomics forthcoming. 
Kuttner, K. N. (2001). Monetary policy surprises and interest rates: Evidence from the fed funds futures market. Journal of Monetary Economics 47(3), 523-544.

Mertens, K. and M. O. Ravn (2019, July). The dynamic effects of personal and corporate income tax changes in the United States: Reply. American Economic Review 109(7), 2679-91.

Miranda-Agrippino, S. and G. Ricco (2018). The transmission of monetary policy shocks. Working Paper.

Montiel Olea, J. L., J. H. Stock, and M. W. Watson (2020). Inference in structural vector autoregressions identified with an external instrument. Journal of Econometrics.

Nakamura, E. and J. Steinsson (2018). High-frequency identification of monetary non-neutrality: The information effect. The Quarterly Journal of Economics 133(3), 1283-1330.

Ramey, V. A. (2016). Macroeconomic shocks and their propagation. Handbook of Macroeconomics 2, 71-162.

Romer, C. D. and D. H. Romer (2004). A new measure of monetary shocks: Derivation and implications. American Economic Review 94(4), 1055-1084.

Romer, D. H. (2002). Advanced macroeconomics. Douglas Reiner.

Sastry, K. A. (2020). Public sentiment and monetary surprises. Working Paper.

Smets, F. and R. Wouters (2007). Shocks and frictions in US business cycles: A Bayesian DSGE approach. National Bank of Belgium Working Paper (109).

Stock, J. H. and M. W. Watson (2002). Macroeconomic forecasting using diffusion indexes. Journal of Business \& Economic Statistics 20(2), 147-162.

Swanson, E. T. (2017). Measuring the effects of unconventional monetary policy on asset prices. National Bureau of Economic Research Working Paper. 
Swanson, E. T. and J. C. Williams (2014). Measuring the effect of the zero lower bound on medium- and longer-term interest rates. The American Economic Review 104(10), 3154-3185.

The Wall Street Journal (1994). Little change for economy seen by some. by Thomas T. Vogel Jr., February 7, 1994, Credit Market.

The Wall Street Journal (2008a). Data expected to confirm deflation trend. by Mark Gongloff, November 26, 2008.

The Wall Street Journal (2008b). Fear recedes in the debt markets. by Michael Aneiro, November 26, 2008, Credit Market.

The Wall Street Journal (2009). Fed's silence on recovery speaks volumes. by Mark Gongloff, March 19, 2009.

Wieland, J. F. and M.-J. Yang (2020). Financial dampening. Journal of Money, Credit and Banking 52(1), 79-113. 
Table 1: White noise test

\begin{tabular}{ll|cccccc}
\hline Statistics & & MP1 & $\triangle$ FF4 & PC1 & RR & MAR & PIR \\
\hline Mean & & -0.01 & -0.01 & 0 & 0 & 0 & 0 \\
Standard deviation & & 0.04 & 0.05 & 0.04 & 0.30 & 0.04 & 0.04 \\
Ljung-Box Q-test p-value & lag 1 & 0.58 & 0.23 & 0.43 & 0.03 & 0.96 & 0.27 \\
& lag 2 & 0.17 & 0.49 & 0.43 & 0.09 & 1 & 0.07 \\
& lag 3 & 0.01 & 0.26 & 0.38 & 0.08 & 1 & 0.14 \\
& lag 4 & 0.01 & 0.04 & 0.16 & 0.16 & 1 & 0.23 \\
& lag 5 & 0.01 & 0.07 & 0.23 & 0 & 1 & 0.22 \\
& lag 6 & 0.02 & 0.11 & 0.20 & 0 & 1 & 0.30 \\
& lag 7 & 0.02 & 0.01 & 0.11 & 0 & 1 & 0.33 \\
& lag 8 & 0.04 & 0.01 & 0.13 & 0 & 1 & 0.33 \\
& lag 9 & 0.04 & 0.01 & 0.15 & 0 & 1 & 0.3 \\
& lag 10 & 0.05 & 0.01 & 0.13 & 0 & 1 & 0.19 \\
& lag 11 & 0.05 & 0.01 & 0.07 & 0 & 1 & 0.26 \\
lag 12 & 0.05 & 0.01 & 0.10 & 0 & 1 & 0.31 \\
\hline
\end{tabular}

NOTES: Ljung-Box Q-test's null hypothesis is that a series exhibits no autocorrelation for a fixed number of lags, and the alternative hypothesis is that some autocorrelation coefficients are nonzero. All shocks are in monthly frequencies. The sample periods for MP1, $\triangle \mathrm{FF} 4, \mathrm{PC} 1$, the RR, the MAR and the PIR are from January 1990 to December 2008, January 1990 to December 2008, January 1990 to December 2018, March 1969 to December 2007, January 1991 to December 2009, and January 1988 to December 2015, respectively. 
Table 2: Predictability of economic news and market sentiment to monetary policy surprises

\begin{tabular}{lccccccc}
\hline & MP1 & $\triangle$ FF4 & PC1 & RR & MAR & PIR & PIR (full sample) \\
\hline Non-farm payroll & $0.52 * *$ & $1.09 * * *$ & $0.98^{* * *}$ & $2.71^{* *}$ & $0.52^{*}$ & 0.39 & 0.09 \\
& $(0.17)$ & $(0.24)$ & $(0.23)$ & $(0.86)$ & $(0.23)$ & $(0.22)$ & $(0.16)$ \\
BBK coincident index & $1.46^{* *}$ & $2.63 * * *$ & $2.39 * *$ & $7.99^{*}$ & 0.89 & 0.35 & -0.20 \\
& $(0.54)$ & $(0.73)$ & $(0.72)$ & $(3.34)$ & $(0.72)$ & $(0.70)$ & $(0.44)$ \\
13-week $\triangle \ln ($ S\&P 500) & 0.08 & 0.13 & $0.21^{*}$ & -0.06 & $0.15^{*}$ & $0.17 *$ & 0.06 \\
& $(0.06)$ & $(0.08)$ & $(0.08)$ & $(0.27)$ & $(0.07)$ & $(0.07)$ & $(0.04)$ \\
Bullish sentiment & 0.02 & 0.05 & 0.05 & $-0.39 *$ & 0.04 & 0.04 & -0.00 \\
Bearish sentiment & $(0.02)$ & $(0.04)$ & $(0.04)$ & $(0.16)$ & $(0.04)$ & $(0.03)$ & $(0.03)$ \\
& -0.01 & -0.05 & -0.05 & 0.31 & -0.01 & -0.01 & 0.02 \\
& $(0.02)$ & $(0.04)$ & $(0.04)$ & $(0.18)$ & $(0.04)$ & $(0.04)$ & $(0.03)$
\end{tabular}

NOTES: Each estimate comes from a separate OLS regression. The dependent variable in each regression is the monetary policy surprise associated with each meeting. The independent variable, in the left-hand column, is the available economic news and sentiment prior to each meeting. The sample period for the first six columns is from January 1990 to December 2007. The last column is from January 1988 to December 2015. Robust standard errors are in parentheses. $*, * *$ and $* * *$ denote statistical significance at $10 \%, 5 \%$ and $1 \%$ levels, respectively. 


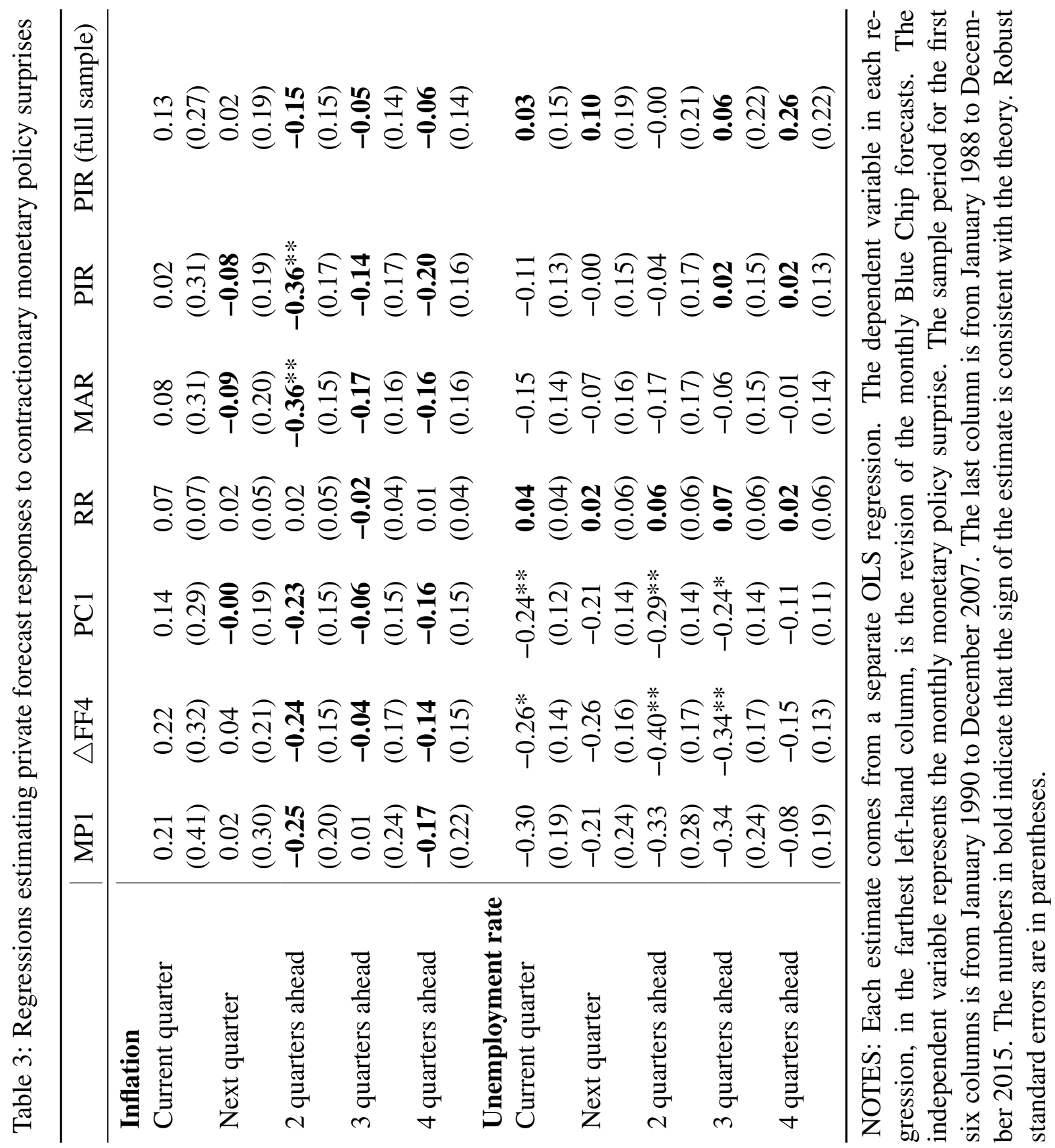


Table 4: Correlations between the stock price index and monetary policy surprises

\begin{tabular}{lccccccc}
\hline \multicolumn{2}{l}{ Panel A: Pearson linear correlation } & & & & & \\
& MP1 & $\triangle \mathrm{FF} 4$ & PC1 & RR & MAR & PIR & PIR (full sample) \\
$\triangle$ S\&P 500 & -0.58 & -0.54 & -0.61 & 0.07 & -0.53 & -0.60 & -0.53 \\
$\triangle$ S\&P 500 futures & -0.62 & -0.59 & -0.66 & 0.05 & -0.56 & -0.64 & -0.58 \\
\hline
\end{tabular}

Panel B: Spearman rank correlation MP1 $\triangle$ FF4 PC1 $\quad$ RR $\quad$ MAR $\quad$ PIR $\quad$ PIR (full sample) $\begin{array}{llllllll}\triangle \text { S\&P } 500 & -0.38 & -0.42 & -0.49 & 0.11 & -0.36 & -0.50 & -0.47\end{array}$ $\begin{array}{llllllll}\triangle \mathrm{S} \& \mathrm{P} 500 \text { futures } & -0.38 & -0.41 & -0.50 & 0.10 & -0.33 & -0.48 & -0.49\end{array}$

NOTES: Pearson's correlation captures the statistical dependence between the levels of two variables whereas Spearman's correlation is a non-parametric measure and captures the degree to which a relationship is monotonic. Changes in the S\&P 500 and S\&P 500 futures, as well as all of the monetary policy surprises except the Romer-Romer, are constructed using 30-minute window data. The sample period for the first six columns is from January 1990 to December 2007. The sample period for the last column is from January 1988 to December 2015. 


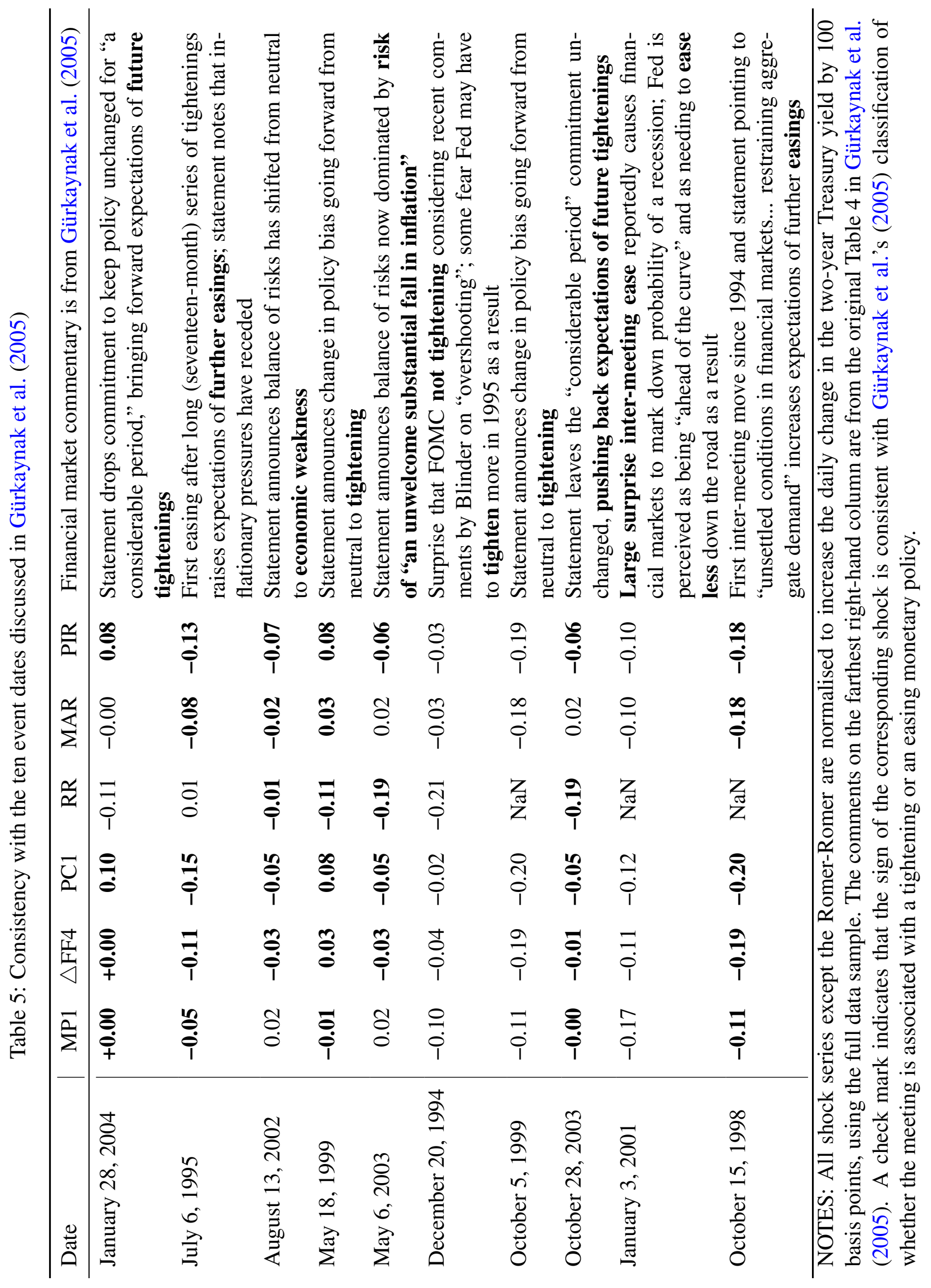




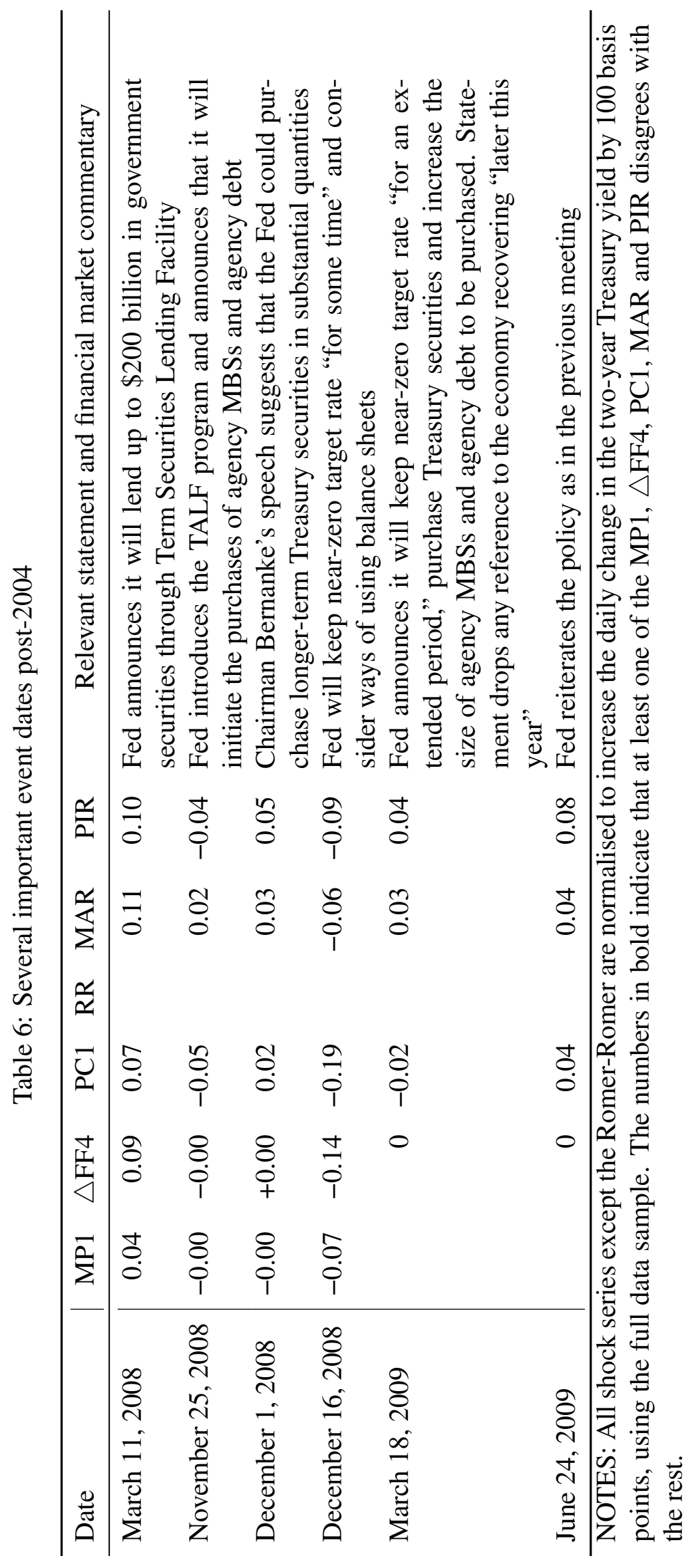




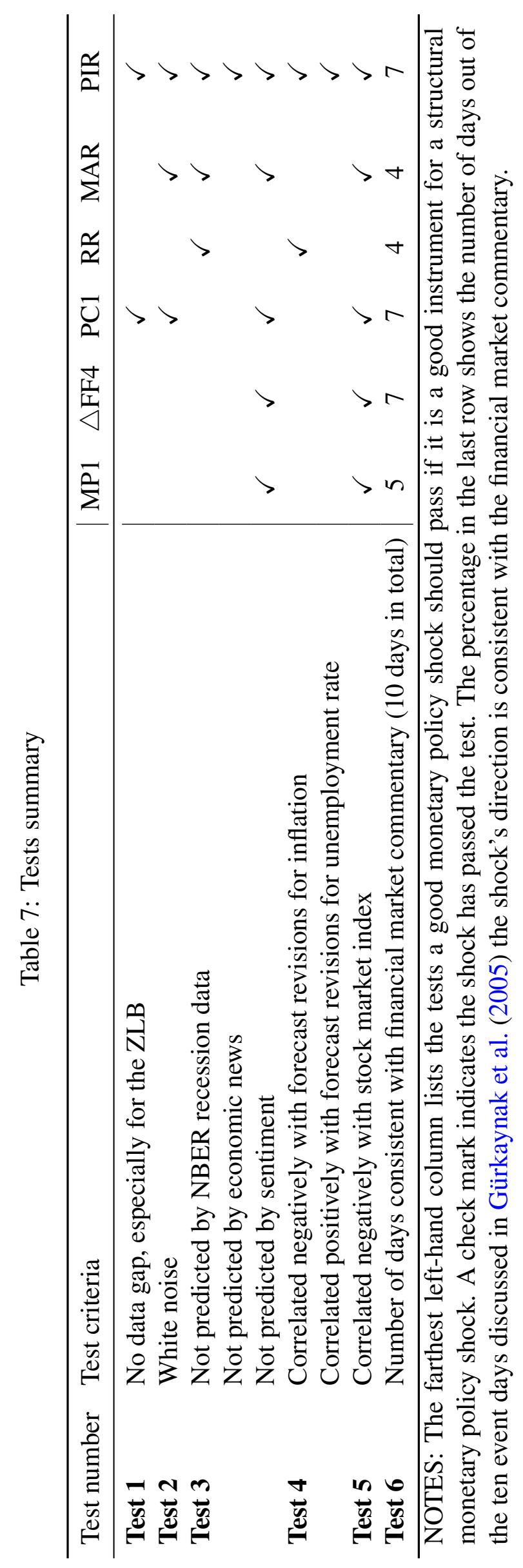


Table 8: Monetary policy shocks' effects on various yields

\begin{tabular}{|c|c|c|c|c|c|c|c|}
\hline & MP1 & $\triangle \mathrm{FF} 4$ & PC1 & $\mathrm{RR}$ & MAR & PIR & PIR (full sample) \\
\hline Nominal 3-month & $\begin{array}{c}1.20 * * * \\
(0.06)\end{array}$ & $\begin{array}{c}0.81 * * * \\
(0.05)\end{array}$ & $\begin{array}{c}0.82 * * * \\
(0.04)\end{array}$ & $\begin{array}{c}0.06 * * * \\
(0.02)\end{array}$ & $\begin{array}{c}0.78 * * * \\
(0.06)\end{array}$ & $\begin{array}{c}0.84 * * * \\
(0.05)\end{array}$ & $\begin{array}{c}0.75 * * * \\
(0.04)\end{array}$ \\
\hline Nominal 6-month & $\begin{array}{c}1.20 * * * \\
(0.08)\end{array}$ & $\begin{array}{c}0.87 * * * \\
(0.06)\end{array}$ & $\begin{array}{c}0.97 * * * \\
(0.03)\end{array}$ & $\begin{array}{c}0.06 * * \\
(0.02)\end{array}$ & $\begin{array}{c}0.83 * * * \\
(0.07)\end{array}$ & $\begin{array}{c}0.99 * * * \\
(0.05)\end{array}$ & $\begin{array}{c}0.90 * * * \\
(0.04)\end{array}$ \\
\hline Nominal 2-year & $\begin{array}{c}1.03 * * * \\
(0.11)\end{array}$ & $\begin{array}{c}0.92 * * * \\
(0.07)\end{array}$ & $\begin{array}{c}1.06 * * * \\
(0.04)\end{array}$ & $\begin{array}{c}0.04 \\
(0.03)\end{array}$ & $\begin{array}{c}0.86 * * * \\
(0.09)\end{array}$ & $\begin{array}{c}1.09 * * * \\
(0.05)\end{array}$ & $\begin{array}{c}1.04 * * * \\
(0.05)\end{array}$ \\
\hline Nominal 5-year & $\begin{array}{c}0.62 * * * \\
(0.11)\end{array}$ & $\begin{array}{c}0.61 * * * \\
(0.07)\end{array}$ & $\begin{array}{c}0.79 * * * \\
(0.05)\end{array}$ & $\begin{array}{c}0.01 \\
(0.03)\end{array}$ & $\begin{array}{c}0.56^{* * * *} \\
(0.08)\end{array}$ & $\begin{array}{c}0.80 * * * \\
(0.06)\end{array}$ & $\begin{array}{c}0.80 * * * \\
(0.06)\end{array}$ \\
\hline Nominal 10-year & $\begin{array}{c}0.27 * * * \\
(0.09)\end{array}$ & $\begin{array}{c}0.31 * * * \\
(0.06)\end{array}$ & $\begin{array}{c}0.47 * * * \\
(0.05)\end{array}$ & $\begin{array}{l}-0.02 \\
(0.02)\end{array}$ & $\begin{array}{c}0.29 * * * \\
(0.07)\end{array}$ & $\begin{array}{c}0.49 * * * \\
(0.05)\end{array}$ & $\begin{array}{c}0.46^{* * *} * \\
(0.07)\end{array}$ \\
\hline Nominal 30-year & $\begin{array}{l}-0.03 \\
(0.07)\end{array}$ & $\begin{array}{l}0.10 * \\
(0.05)\end{array}$ & $\begin{array}{c}0.21 * * * \\
(0.05)\end{array}$ & $\begin{array}{c}-0.04 * * \\
(0.02)\end{array}$ & $\begin{array}{c}0.08 \\
(0.06)\end{array}$ & $\begin{array}{c}0.21 * * * \\
(0.05)\end{array}$ & $\begin{array}{c}0.18 * * * \\
(0.06)\end{array}$ \\
\hline TIPS 2-year & $\begin{array}{c}0.92 * * \\
(0.40)\end{array}$ & $\begin{array}{c}0.96 * * * \\
(0.21)\end{array}$ & $\begin{array}{c}0.99 * * * \\
(0.11)\end{array}$ & $\begin{array}{c}0.04 \\
(0.04)\end{array}$ & $\begin{array}{c}0.70 * * * \\
(0.22)\end{array}$ & $\begin{array}{c}0.80 * * * \\
(0.14)\end{array}$ & $\begin{array}{c}0.83 * * * \\
(0.14)\end{array}$ \\
\hline TIPS 10-year & $\begin{array}{l}0.44 * \\
(0.26)\end{array}$ & $\begin{array}{c}0.59 * * * \\
(0.19)\end{array}$ & $\begin{array}{c}0.74 * * * \\
(0.09)\end{array}$ & $\begin{array}{l}-0.01 \\
(0.03)\end{array}$ & $\begin{array}{c}0.38 * * \\
(0.18)\end{array}$ & $\begin{array}{c}0.63 * * * \\
(0.10)\end{array}$ & $\begin{array}{c}0.59 * * * \\
(0.12)\end{array}$ \\
\hline
\end{tabular}

NOTES: Each estimate comes from a separate OLS regression. The dependent variable in each regression, in the left-hand column, is the intraday change in various interest rates. The independent variable is the monetary policy surprise at the meeting level. The sample period for the first six columns is from January 1990 to December 2007. The sample period for the last column is from January 1988 to December 2015. Robust standard errors are in parentheses; *, ** and *** denote statistical significance at 10,5 and 1 percent levels, respectively. 


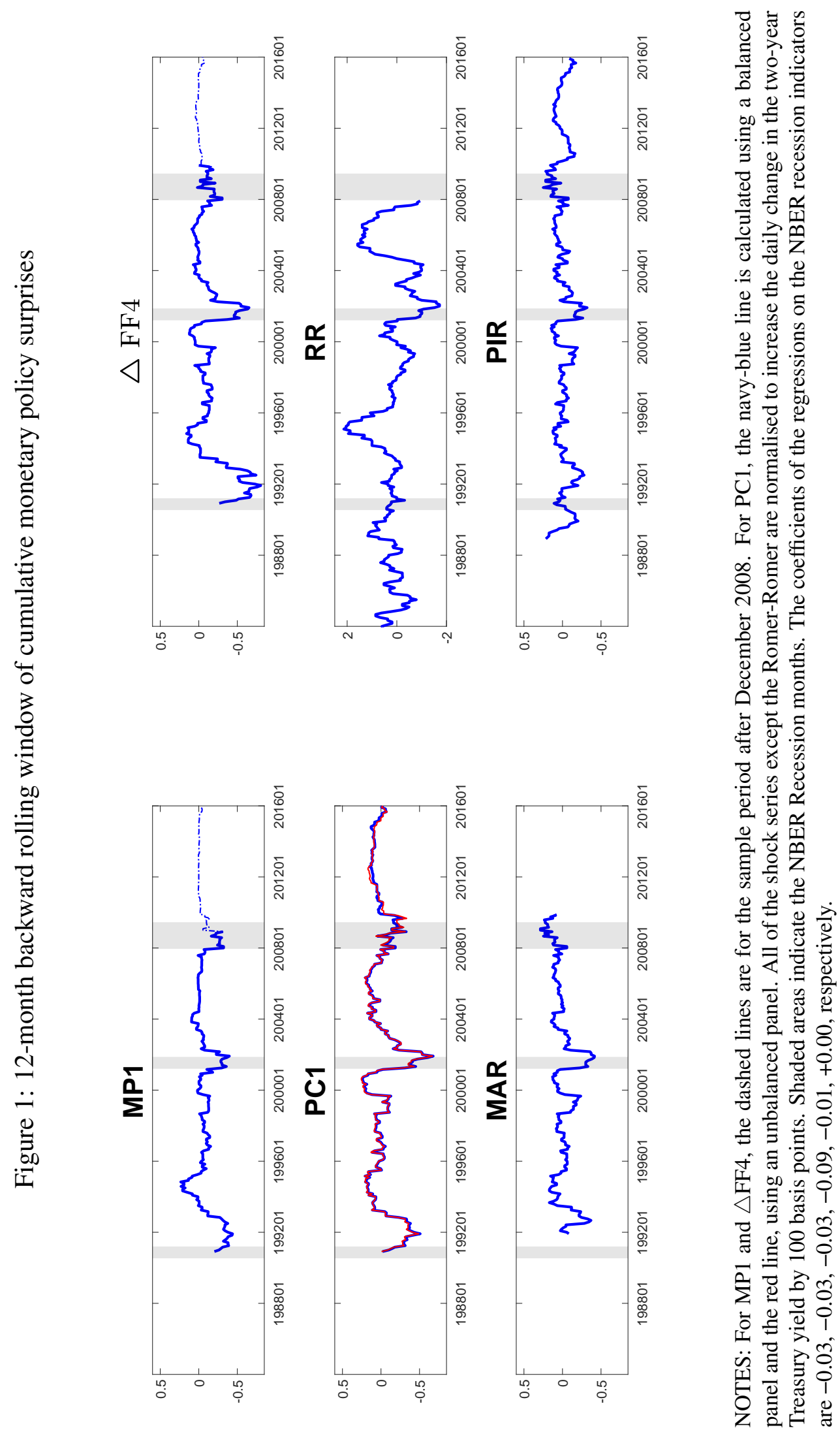




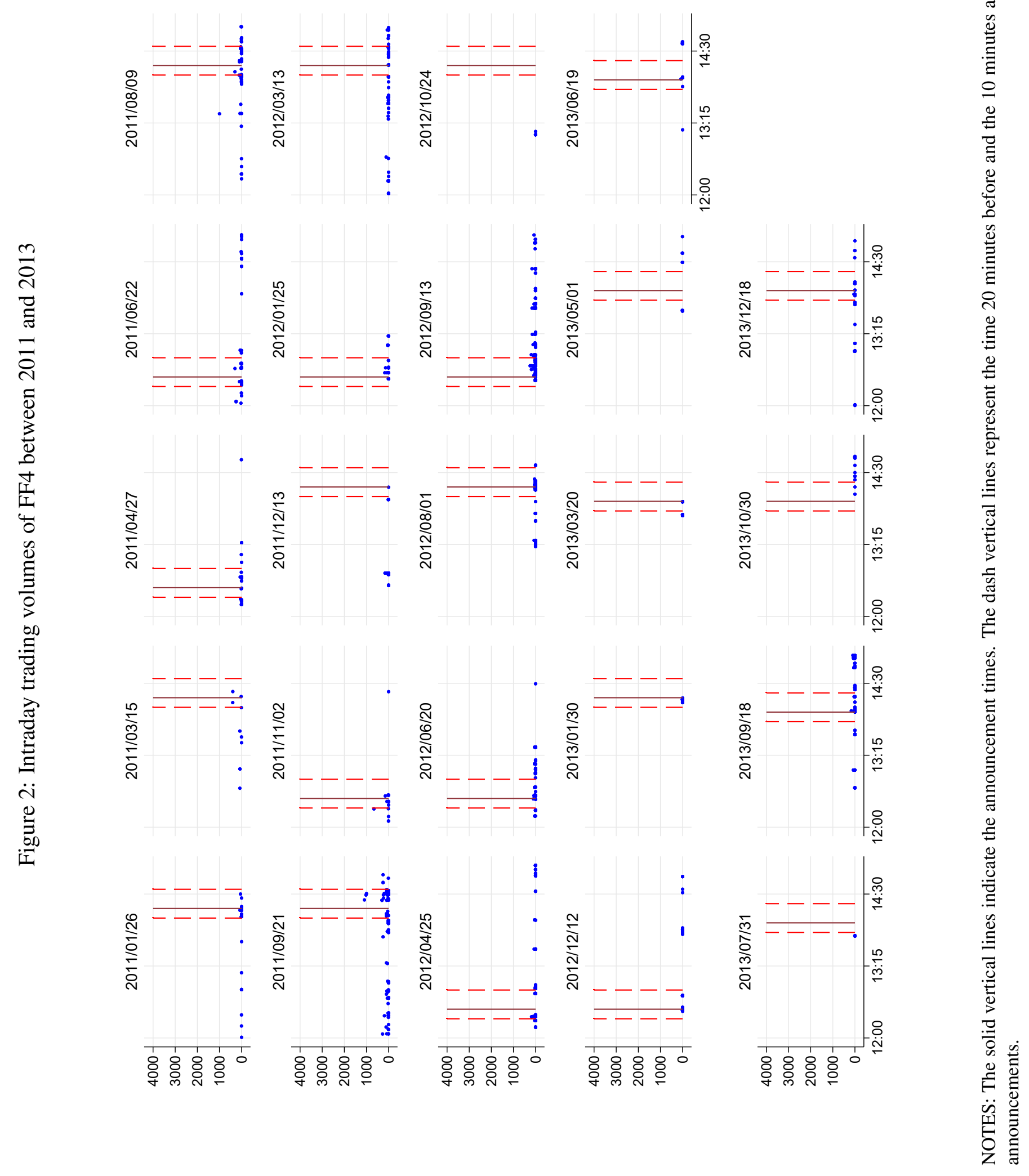



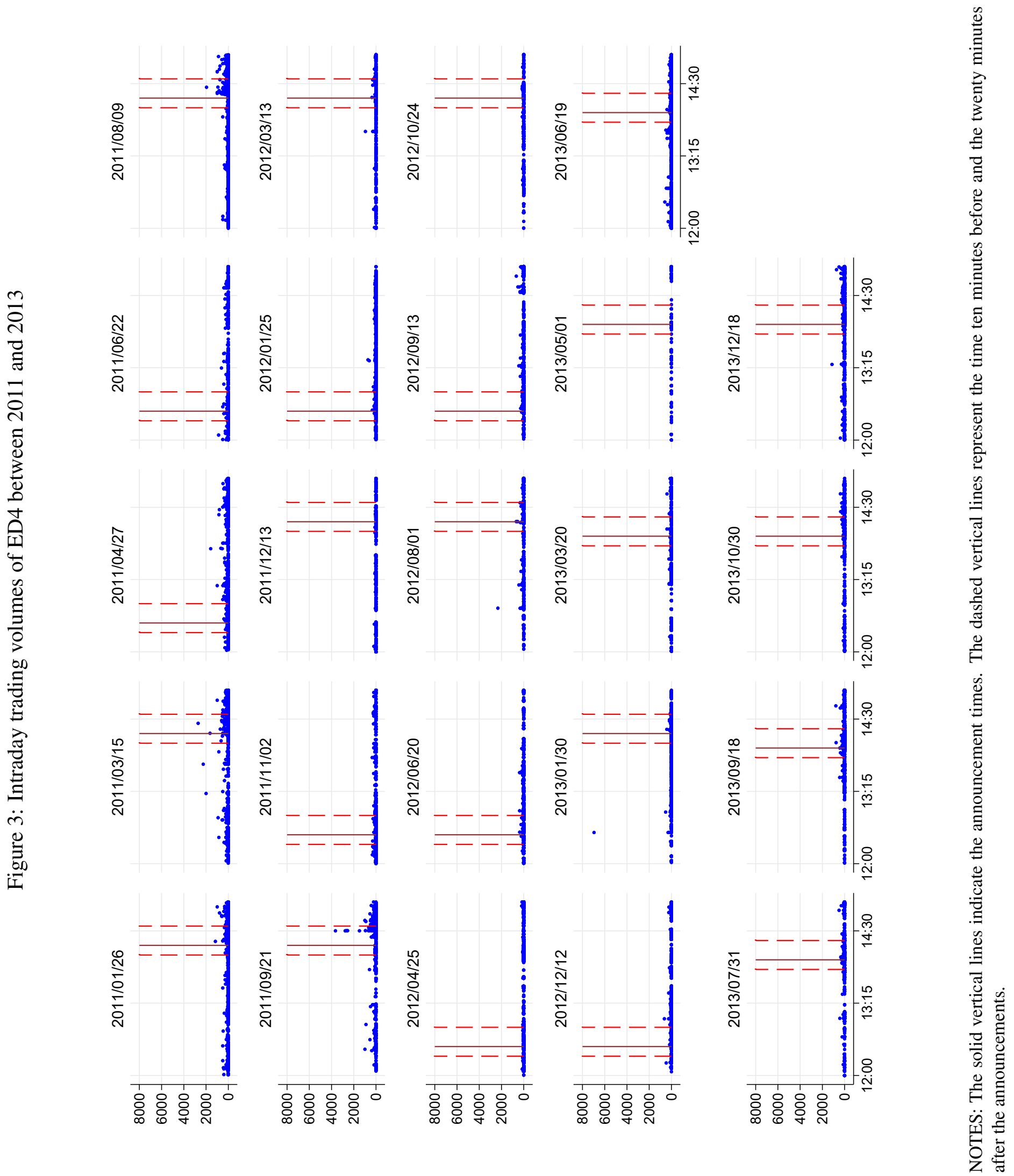

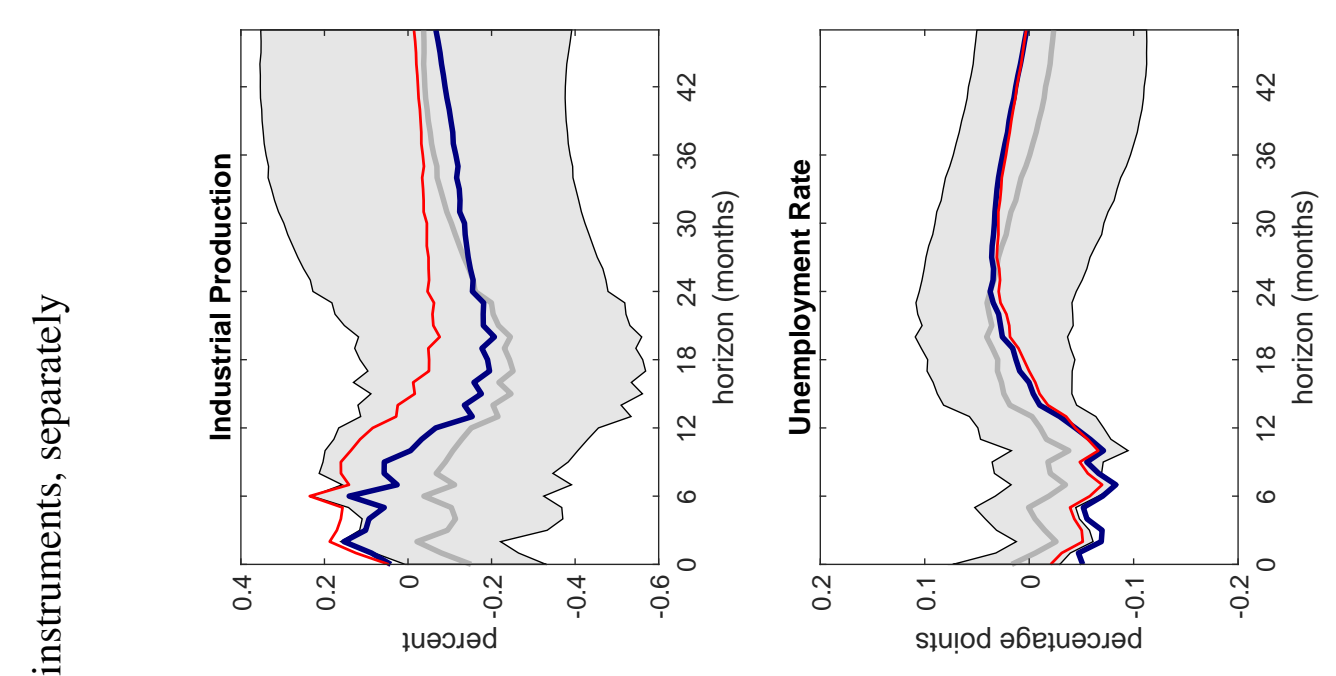

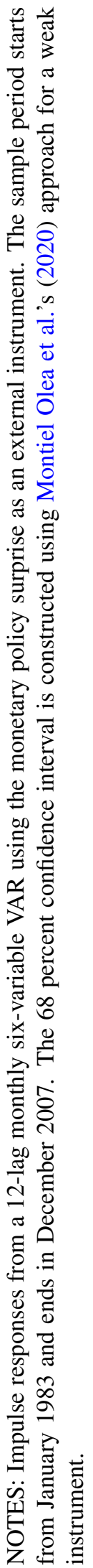




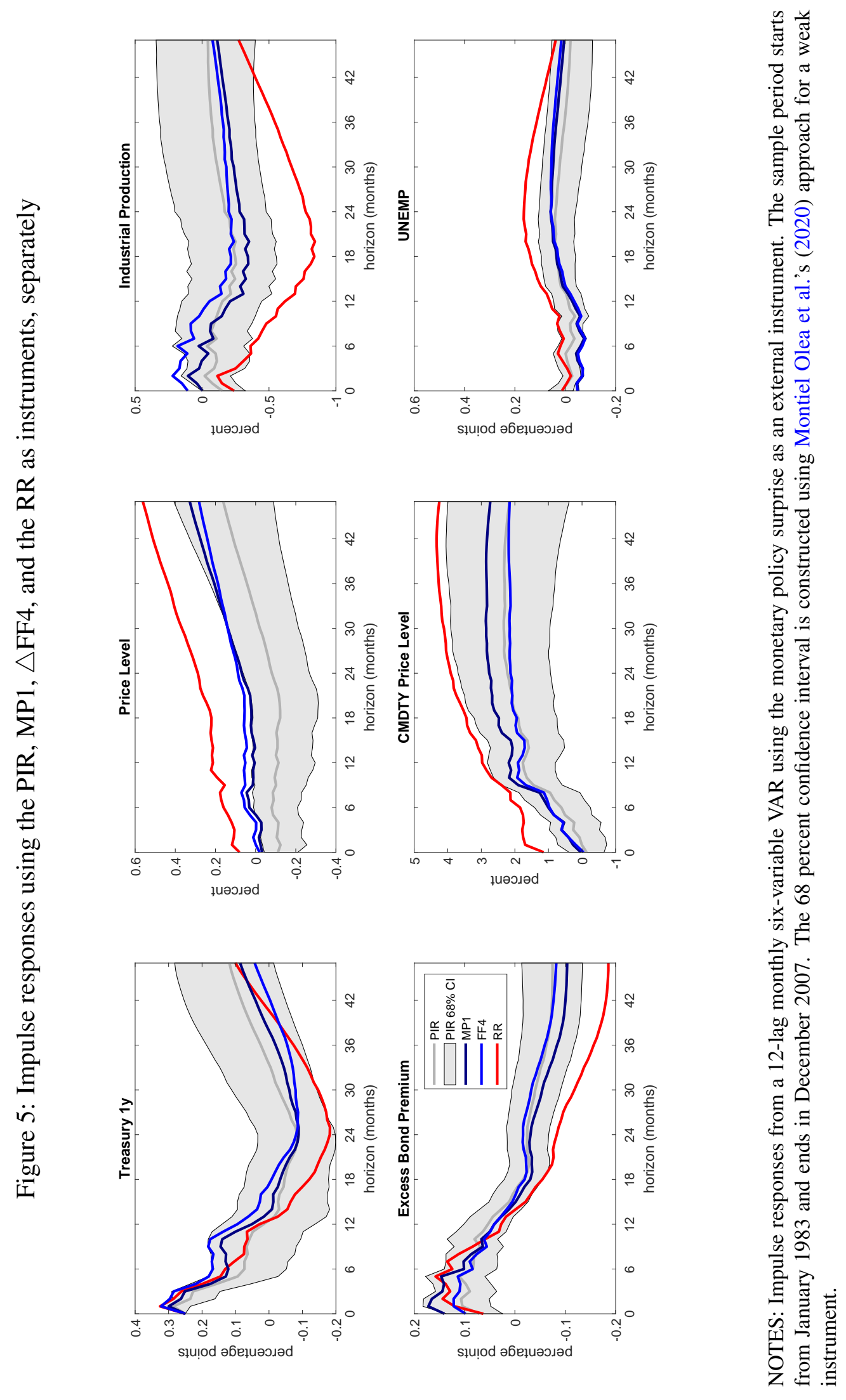

